\title{
Adverse events following immunisation with a meningococcal serogroup B vaccine: report from post- marketing surveillance, Germany, 2013 to 2016
}

Dirk Mentzer ${ }^{1,2}$, Doris Oberle ${ }^{1,2}$, Brigitte Keller-Stanislawski ${ }^{1}$

1. Department Safety of Medicinal Products and Medical Devices, Paul-Ehrlich-Institut, Federal Institute for Vaccines and Biomedicines, Langen, Germany

2. DM and DO contributed equally to this article

Correspondence: Doris Franziska Oberle (doris.oberle@pei.de)

Citation style for this article:

Mentzer Dirk, Oberle Doris, Keller-Stanislawski Brigitte. Adverse events following immunisation with a meningococcal serogroup B vaccine: report from postmarketing surveillance, Germany, 2013 to 2016. Euro Surveill. 2018;23(17):pii=17-00468. https://doi.org/10.2807/1560-7917. ES.2018.23.17.17-00468

Background and aim: In January 2013, a novel vaccine against Neisseria meningitidis serogroup $\mathrm{B}$, the multicomponent meningococcal serogroup $B$ vaccine (4CMenB), was approved by the European Medicines Agency. We aimed to evaluate the safety profile of this vaccine. Methods: All adverse events following immunisation (AEFI) reported from Germany since the vaccine's launch in Germany in November 2013 through December 2016 were reviewed and analysed. Results: Through December 2016, a total of 664 individual case safety reports (ICSR) notifying $1,960 \mathrm{AEFI}$ were received. A majority of vaccinees for whom $A E F I$ were reported were children 2 to 11 years of age $(n=280$; $42.2 \%)$ followed by infants and toddlers aged 28 days to 23 months $(n=170 ; 25.6 \%)$. General disorders and administration site conditions was the System Organ Class (SOC) with the majority of AEFI $(n=977 ; 49.8 \%)$, followed by nervous system disorders $(n=249 ; 12.7 \%)$, and skin and subcutaneous tissue disorders $(n=191$; $9.7 \%$ ). Screening of patient records for immune-mediated and neurological diseases did not raise any safety signal in terms of an increased proportional reporting ratio (PRR). Conclusions: The safety profile described in the Summary of Product Characteristics, in general, is confirmed by data from spontaneous reporting. No safety concerns were identified.

\section{Introduction}

Infection with Neisseria meningitidis, an aerobic encapsulated Gram-negative diplococcus, may be life-threatening or result in major long-term sequelae.

In 2015, within the scope of a surveillance programme coordinated by the European Centre of Disease Prevention and Control (ECDC), the notification rate of invasive meningococcal disease was 0.6 cases per 100,000 population (lower and upper bound: 0.1-2.0) in the European Union/European Economic
Area (EU/EEA) and 0.4 cases per 100,000 population in Germany [1]. Particularly high age-specific rates in the EU/EEA were found in infants under one year of age at 10.0 cases per 100,000 population and in children 1 to 4 years of age at 2.8 cases per 100,000 population [1]. The majority of cases with a known serogroup belonged to serogroup B (61\%) [1].

Until 2012, no broadly effective serogroup B meningococcal vaccines were available as the capsular polysaccharide of meningococcal serogroup $B$ is poorly immunogenic in humans $[2,3]$. This is why research has focused on proteins in the outer membrane of meningococci as potential antigens for candidate vaccines $[2,3]$.

The multicomponent meningococcal serogroup $B$ vaccine (4CMenB), Bexsero (GSK Vaccines S.r.l., Siena, Italy), contains four antigenic components: factor $H$ binding protein, Neisseria adhesin A, Neisseria heparin-binding antigen and outer membrane vesicles from a New Zealand epidemic strain that produces Porin A, the immunodominant antigen that is present in the outer membrane vesicle component [4].

We aimed to evaluate and complement the safety profile of 4 CMenB as described in the Summary of Product Characteristics. A special focus was placed on immunemediated and severe neurological outcomes.

\section{Methods}

Adverse events following immunisation (AEFI) with 4CMenB reported in Germany since the vaccine's launch on the German market on 27 November 2013 through 31 December 2016 were reviewed. 
TABLE 1

Reporting year and demographic characteristics of multicomponent meningococcal serogroup B vaccine (4CMenB) recipients addressed in individual case safety reports (ICSR), Germany, 2013-2016 (n = 664)

\begin{tabular}{|c|c|c|c|c|c|c|c|c|c|c|c|c|c|c|}
\hline \multirow{3}{*}{ Reporting year and sex } & \multicolumn{12}{|c|}{ Age group } & \multirow{2}{*}{\multicolumn{2}{|c|}{ Total }} \\
\hline & \multicolumn{2}{|c|}{$\begin{array}{l}28 \text { days }-23 \\
\text { months }^{\mathrm{a}}\end{array}$} & \multicolumn{2}{|c|}{$2-11$ years } & \multicolumn{2}{|c|}{$12-17$ years } & \multicolumn{2}{|c|}{$18-59$ years } & \multicolumn{2}{|c|}{$\geq 60$ years } & \multicolumn{2}{|c|}{ NA } & & \\
\hline & $\mathrm{n}$ & $\%$ & $n$ & $\%$ & $n$ & $\%$ & $\mathrm{n}$ & $\%$ & $\mathrm{n}$ & $\%$ & $n$ & $\%$ & $n$ & $\%$ \\
\hline \multicolumn{15}{|l|}{ Reporting year } \\
\hline 2013 & 1 & 0.6 & 0 & 0.0 & 0 & 0.0 & 0 & 0.0 & 0 & 0.0 & 1 & 1.7 & 2 & 0.3 \\
\hline 2014 & 47 & 27.6 & 97 & 34.6 & 22 & 37.3 & 41 & 44.1 & 1 & 50.0 & 31 & 51.7 & 239 & 36.0 \\
\hline 2015 & 48 & 28.2 & 97 & 34.6 & 14 & 23.7 & 19 & 20.4 & 0 & 0.0 & 16 & 26.7 & 194 & 29.2 \\
\hline 2016 & 74 & 43.5 & 86 & 30.7 & 23 & 39.0 & 33 & 35.5 & 1 & 50.0 & 12 & 20.0 & 229 & 34.5 \\
\hline \multicolumn{15}{|l|}{ Sex } \\
\hline Male & 76 & 44.7 & 140 & 50.0 & 22 & 37.3 & 29 & 31.2 & 0 & 0.0 & 23 & 38.3 & 290 & 43.7 \\
\hline Female & 86 & 50.6 & 118 & 42.1 & 35 & 59.3 & 61 & 65.6 & 2 & 100 & 19 & 31.7 & 321 & 48.3 \\
\hline NA & 8 & 4.7 & 22 & 7.9 & 2 & 3.4 & 3 & 3.2 & 0 & 0.0 & 18 & 30.0 & 53 & 8.0 \\
\hline Total & 170 & 100 & 280 & 100 & 59 & 100 & 93 & 100 & 2 & 100 & 60 & 100 & 664 & 100 \\
\hline
\end{tabular}

NA: not available.

a There was one medication error where vaccine was administered to an infant that was too young, being 44 days of age at time of vaccination.

\section{TABLE 2}

Outcome and causality assessment of individual case safety reports (ICSR) following immunisation with multicomponent meningococcal serogroup B vaccine (4CMenB) by age group, Germany, 2013-2016 ( $=664)$

\begin{tabular}{|c|c|c|c|c|c|c|c|c|c|c|c|c|c|c|}
\hline \multirow{3}{*}{$\begin{array}{l}\text { Outcome and causality } \\
\text { assessment }\end{array}$} & \multicolumn{12}{|c|}{ Age group } & \multirow{2}{*}{\multicolumn{2}{|c|}{ Total }} \\
\hline & \multicolumn{2}{|c|}{28 days -23 months } & \multicolumn{2}{|c|}{ 2-11 years } & \multicolumn{2}{|c|}{$12-17$ years } & \multicolumn{2}{|c|}{$18-59$ years } & \multicolumn{2}{|c|}{$\geq 60$ years } & \multicolumn{2}{|c|}{ NA } & & \\
\hline & $n$ & $\%$ & $\mathrm{n}$ & $\%$ & $n$ & $\%$ & $n$ & $\%$ & $\mathrm{n}$ & $\%$ & $n$ & $\%$ & $\mathrm{n}$ & $\%$ \\
\hline \multicolumn{15}{|l|}{ Outcome $^{a}$} \\
\hline Recovered & 94 & $55 \cdot 3$ & 151 & 53.9 & 34 & 57.6 & 53 & 57.0 & 1 & 50.0 & 25 & 41.7 & 358 & 53.9 \\
\hline Improved & 6 & 3.5 & 13 & 4.6 & 1 & 1.7 & 5 & 5.4 & 0 & 0.0 & 0 & 0.0 & 25 & 3.8 \\
\hline Not recovered & 24 & 14.1 & 25 & 8.9 & 2 & 3.4 & 10 & 10.8 & 1 & 50.0 & 3 & 5.0 & 65 & 9.8 \\
\hline Sequelae & 1 & 0.6 & 0 & 0.0 & 0 & 0.0 & 0 & 0.0 & 0 & 0.0 & 0 & 0.0 & 1 & 0.2 \\
\hline Death & 0 & 0.0 & 1 & 0.4 & 0 & 0.0 & 0 & 0.0 & 0 & 0.0 & 0 & 0.0 & 1 & 0.2 \\
\hline Unknown & 45 & 26.5 & 90 & 32.1 & 22 & 37.3 & 25 & 26.9 & 0 & 0.0 & 32 & 53.3 & 214 & 32.2 \\
\hline \multicolumn{15}{|l|}{ Causality assessment $^{b}$} \\
\hline Consistent & 123 & 72.4 & 189 & 67.5 & 41 & 69.5 & 59 & 63.4 & 2 & 100 & 38 & 63.3 & 452 & 68.1 \\
\hline Indeterminate & 5 & 2.9 & 9 & 3.2 & 0 & 0.0 & 2 & 2.2 & 0 & 0.0 & 1 & 1.7 & 17 & 2.6 \\
\hline Inconsistent & 11 & 6.5 & 21 & 7.5 & 2 & 3.4 & 13 & 14.0 & 0 & 0.0 & 3 & 5.0 & 50 & 7.5 \\
\hline Unclassifiable & 31 & 18.2 & 61 & 21.8 & 16 & 27.1 & 19 & 20.4 & 0 & 0.0 & 18 & 30.0 & 145 & 21.8 \\
\hline Total & 170 & 100 & 280 & 100 & 59 & 100 & 93 & 100 & 2 & 100 & 60 & 100 & 664 & 100 \\
\hline
\end{tabular}

NA: not available.

at the date of reporting.

${ }^{b}$ Causality of an ICSR was assessed according to the revised World Health Organization (WHO) classification [13].

\section{Spontaneous reporting}

Germany has a mandatory reporting system for $\mathrm{AEFI}$ that is used for vaccine safety surveillance. According to $\$ 6(3)$ of the Protection against Infection Act (Infektionsschutzgesetz, IfSG) [5], it is mandatory for healthcare professionals to report AEFI to the local health authorities which themselves are obliged to forward the notification to the national competent authority. Marketing authorisation holders have to report suspected serious adverse reactions directly to the national competent authority according to $\S 63 \mathrm{C}$ of the German Medicinal Products Act (Arzneimittelgesetz, AMG) [6]. In addition, vaccinees or their relatives may notify AEFI, so-called consumer reports, via an online database. The seriousness of individual case safety reports (ICSR) was determined according the 
Adverse events following immunisation (AEFI) with multicomponent meningococcal serogroup B vaccine (4CMenB) by System Organ Class (SOC) and age group, Germany, 2013-2016 ( $\mathrm{n}=1,960)$

\begin{tabular}{|c|c|c|c|c|c|c|c|c|c|c|c|c|c|c|}
\hline \multirow{3}{*}{$\mathrm{SOC}$} & \multicolumn{12}{|c|}{ Age group } & \multirow{2}{*}{\multicolumn{2}{|c|}{ Total }} \\
\hline & \multicolumn{2}{|c|}{28 days -23 months } & \multicolumn{2}{|c|}{$2-11$ years } & \multicolumn{2}{|c|}{$12-17$ years } & \multicolumn{2}{|c|}{$18-59$ years } & \multicolumn{2}{|c|}{$\begin{array}{l}\geq 60 \\
\text { years }\end{array}$} & \multicolumn{2}{|c|}{ NA } & & \\
\hline & $\mathrm{n}$ & $\%$ & $\mathrm{n}$ & $\%$ & $n$ & $\%$ & $n$ & $\%$ & $\mathrm{n}$ & $\%$ & $n$ & $\%$ & $\mathrm{n}$ & $\%$ \\
\hline $\begin{array}{l}\text { General disorders and } \\
\text { administration site } \\
\text { conditions }\end{array}$ & 195 & 41.6 & 442 & 53.9 & 85 & 48.0 & 173 & 53.2 & 2 & 66.7 & 80 & 48.2 & 977 & 49.8 \\
\hline Nervous system disorders & 68 & 14.5 & 86 & 10.5 & 24 & 13.6 & 47 & $14 \cdot 5$ & 1 & 33.3 & 23 & 13.9 & 249 & 12.7 \\
\hline $\begin{array}{l}\text { Skin and subcutaneous } \\
\text { tissue disorders }\end{array}$ & 47 & 10.0 & 90 & 11.0 & 13 & $7 \cdot 3$ & 29 & 8.9 & 0 & 0.0 & 12 & 7.2 & 191 & 9.7 \\
\hline $\begin{array}{l}\text { Musculoskeletal and } \\
\text { connective tissue disorders }\end{array}$ & 19 & 4.1 & 58 & 7.1 & 22 & 12.4 & 36 & 11.1 & 0 & 0.0 & 15 & 9.0 & 150 & $7 \cdot 7$ \\
\hline Gastrointestinal disorders & 17 & 3.6 & 37 & 4.5 & 12 & 6.8 & 10 & 3.1 & 0 & 0.0 & 7 & 4.2 & 83 & 4.2 \\
\hline Psychiatric disorders & 46 & 9.8 & 19 & 2.3 & 3 & 1.7 & 3 & 0.9 & 0 & 0.0 & 4 & 2.4 & 75 & 3.8 \\
\hline Investigations & 10 & 2.1 & 19 & 2.3 & 3 & 1.7 & 5 & 1.5 & 0 & 0.0 & 2 & 1.2 & 39 & 2.0 \\
\hline Infections and infestations & 14 & 3.0 & 14 & 1.7 & 0 & 0.0 & 4 & 1.2 & 0 & 0.0 & 4 & 2.4 & 36 & 1.8 \\
\hline Vascular disorders & 12 & 2.6 & 14 & 1.7 & 5 & 2.8 & 2 & 0.6 & 0 & 0.0 & 0 & 0.0 & 33 & 1.7 \\
\hline $\begin{array}{l}\text { Injury, poisoning and } \\
\text { procedural complications }\end{array}$ & 5 & 1.1 & 11 & 1.3 & 2 & 1.1 & 4 & 1.2 & 0 & 0.0 & 5 & 3.0 & 27 & 1.4 \\
\hline $\begin{array}{l}\text { Respiratory, thoracic and } \\
\text { mediastinal disorders }\end{array}$ & 11 & 2.3 & 6 & 0.7 & 2 & 1.1 & 0 & 0.0 & 0 & 0.0 & 6 & 3.6 & 25 & 1.3 \\
\hline Cardiac disorders & 8 & 1.7 & 4 & 0.5 & 3 & 1.7 & 3 & 0.9 & 0 & 0.0 & o & 0.0 & 18 & 0.9 \\
\hline $\begin{array}{l}\text { Blood and lymphatic system } \\
\text { disorders }\end{array}$ & 1 & 0.2 & 4 & 0.5 & 0 & 0.0 & 5 & 1.5 & 0 & 0.0 & 4 & 2.4 & 14 & 0.7 \\
\hline $\begin{array}{l}\text { Metabolism and nutrition } \\
\text { disorders }\end{array}$ & 8 & 1.7 & 5 & 0.6 & 0 & 0.0 & 1 & 0.3 & 0 & 0.0 & 0 & 0.0 & 14 & 0.7 \\
\hline Eye disorders & 3 & 0.6 & 6 & 0.7 & 1 & 0.6 & 1 & 0.3 & 0 & 0.0 & 0 & 0.0 & 11 & 0.6 \\
\hline Product issues & 0 & 0.0 & 0 & 0.0 & 2 & 1.1 & 2 & 0.6 & 0 & 0.0 & 1 & 0.6 & 5 & 0.3 \\
\hline Ear and labyrinth disorders & 2 & 0.4 & 1 & 0.1 & 0 & 0.0 & 0 & 0.0 & 0 & 0.0 & 1 & 0.6 & 4 & 0.2 \\
\hline Renal and urinary disorders & 1 & 0.2 & 1 & 0.1 & 0 & 0.0 & 0 & 0.0 & 0 & 0.0 & 1 & 0.6 & 3 & 0.2 \\
\hline Immune system disorders & 0 & 0.0 & 2 & 0.2 & 0 & 0.0 & 0 & 0.0 & 0 & 0.0 & 0 & 0.0 & 2 & 0.1 \\
\hline Social circumstances & o & 0.0 & 1 & 0.1 & 0 & 0.0 & o & 0.0 & 0 & 0.0 & 1 & 0.6 & 2 & 0.1 \\
\hline $\begin{array}{l}\text { Neoplasms benign, } \\
\text { malignant and unspecified } \\
\text { (including cysts and polyps) }\end{array}$ & 1 & 0.2 & 0 & 0.0 & 0 & 0.0 & 0 & 0.0 & 0 & 0.0 & o & 0.0 & 1 & 0.1 \\
\hline $\begin{array}{l}\text { Pregnancy, puerperium and } \\
\text { perinatal conditions }\end{array}$ & 1 & 0.2 & 0 & 0.0 & 0 & 0.0 & 0 & 0.0 & 0 & 0.0 & 0 & 0.0 & 1 & 0.1 \\
\hline Total & 469 & 100 & 820 & 100 & 177 & 100 & 325 & 100 & 3 & 100 & 166 & 100 & 1,960 & 100 \\
\hline
\end{tabular}

NA: not available.

International Council for Harmonisation (ICH) Topic E 2 A guideline [7]. We reviewed all ICSR received from 2013 to 2016, including consumer reports.

After the launch of ${ }_{4} \mathrm{CMenB}$ in Germany in November 2013, the national competent authority agreed with the marketing authorisation holder on a monthly expedited reporting of non-serious AEFI in addition to the expedited reporting of serious AEFI.

All AEFI included in ICSR were coded by trained data entry staff according to the Medical Dictionary for Regulatory Activities (MedDRA) [8] in Lowest Level Terms (LLTs), the coding level that provides maximum specificity. In MedDRA terminology, selection of a
LLT leads to automatic assignment of grouping terms higher in the hierarchy: Preferred Terms (PTs), High Level Terms (HLTs), High Level Group Terms (HLGTs) and System Organ Classes (SOCs).

\section{Definition of age groups}

Age groups concerning individuals 17 years of age and under were defined according to ICH guideline, Clinical Investigation of Medicinal Products in the Paediatric Population E11 [9]: newborns (o to 27 days of age), infants and toddlers (28 days to 23 months of age), children ( 2 to 11 years of age) and adolescents (12 to 17 years of age). Adults were stratified into two groups: individuals 18 to 59 years of age and those 60 years of age and over. 
TABLE 4A

Preferred Terms (PT) for adverse events following immunisation (AEFI) with multicomponent meningococcal serogroup B vaccine (4CMenB) that were coded at least three times, grouped under High Level Terms (HLT), High Level Group Terms (HLGT) and System Organ Class (SOC), Germany, 2013-2016 (n =1,685)

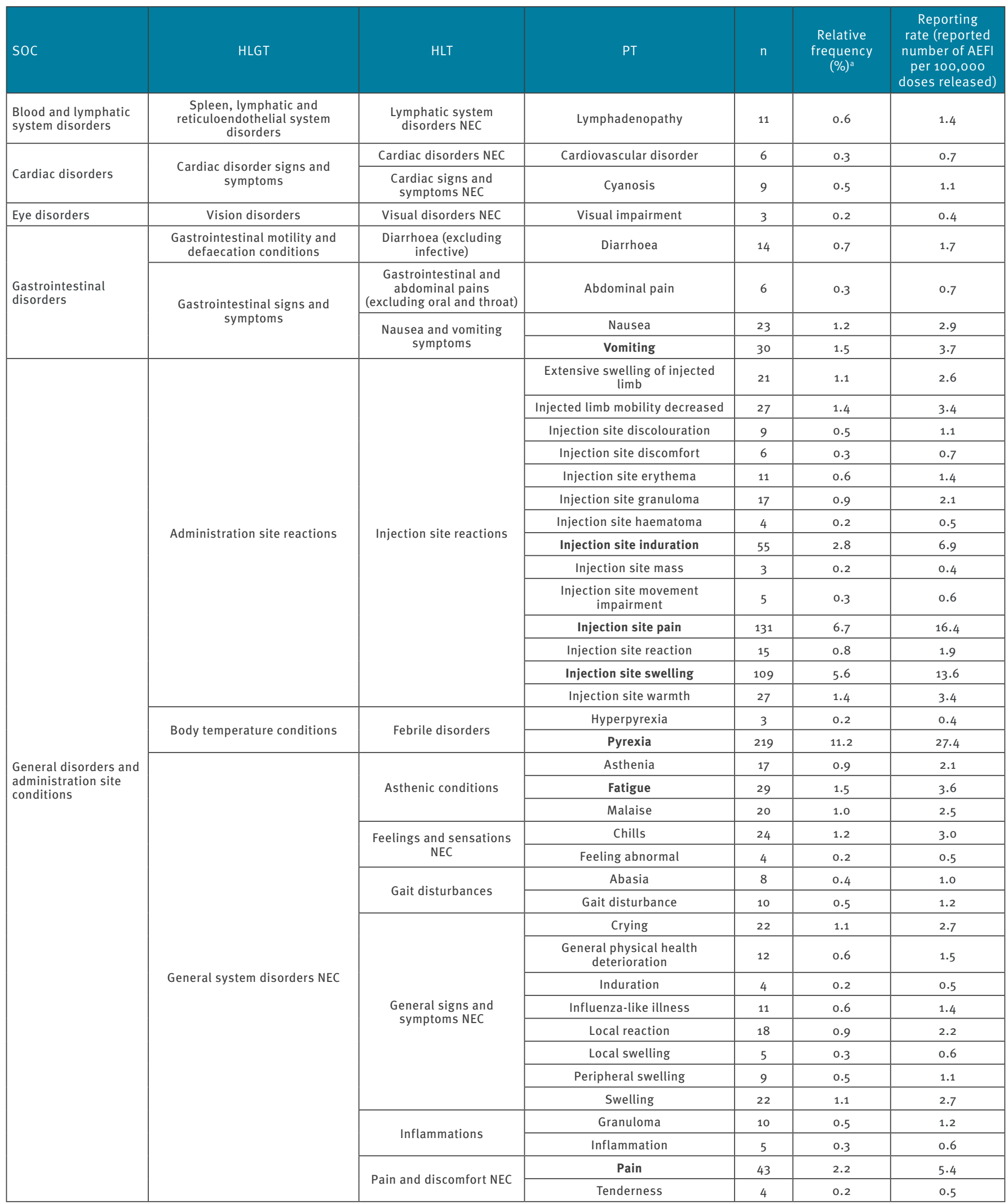

HLGT: High Level Group Terms; HLT: High Level Terms; NEC: not elsewhere classified; PT: Preferred Terms; SOC: System Organ Class.

a Denominator is all reported AEFI $(n=1,960)$.

The ten most frequently coded Preferred Terms (PT) are in bold. 
Preferred Terms (PT) for adverse events following immunisation (AEFI) with multicomponent meningococcal serogroup B vaccine (4CMenB) that were coded at least three times, grouped under High Level Terms (HLT), High Level Group Terms (HLGT) and System Organ Class (SOC), Germany, 2013-2016 ( $\mathrm{n}=1,685)$

\begin{tabular}{|c|c|c|c|c|c|c|}
\hline $\mathrm{SOC}$ & HLGT & HLT & PT & $\mathrm{n}$ & $\begin{array}{l}\text { Relative } \\
\text { frequency } \\
(\%)^{\mathrm{a}}\end{array}$ & $\begin{array}{c}\text { Reporting } \\
\text { rate (reported } \\
\text { number of AEFI } \\
\text { per } 100,000 \\
\text { doses released) }\end{array}$ \\
\hline \multirow{4}{*}{$\begin{array}{l}\text { Infections and } \\
\text { infestations }\end{array}$} & \multirow{4}{*}{ Infections (pathogen unspecified) } & Infections NEC & Infection & 4 & 0.2 & 0.5 \\
\hline & & $\begin{array}{l}\text { Lower respiratory tract } \\
\text { and lung infections }\end{array}$ & Pneumonia & 4 & 0.2 & 0.5 \\
\hline & & $\begin{array}{l}\text { Upper respiratory tract } \\
\text { infections }\end{array}$ & Nasopharyngitis & 4 & 0.2 & 0.5 \\
\hline & & Vascular infections & Lymphangitis & 3 & 0.2 & 0.4 \\
\hline \multirow{3}{*}{$\begin{array}{l}\text { Injury, poisoning } \\
\text { and procedural } \\
\text { complications }\end{array}$} & Injuries NEC & $\begin{array}{l}\text { Non-site specific injuries } \\
\text { NEC }\end{array}$ & Fall & 3 & 0.2 & 0.4 \\
\hline & \multirow[b]{2}{*}{ Medication errors } & \multirow[b]{2}{*}{ Maladministrations } & Expired product administered & 5 & 0.3 & 0.6 \\
\hline & & & $\begin{array}{c}\text { Inappropriate schedule of drug } \\
\text { administration }\end{array}$ & 7 & 0.4 & 0.9 \\
\hline \multirow[t]{2}{*}{ Investigations } & $\begin{array}{l}\text { Physical examination and organ } \\
\text { system status topics }\end{array}$ & $\begin{array}{l}\text { Physical examination } \\
\text { procedures and organ } \\
\text { system status }\end{array}$ & Body temperature increased & 14 & 0.7 & 1.7 \\
\hline & $\begin{array}{l}\text { Protein and chemistry analyses } \\
\text { NEC }\end{array}$ & Protein analyses NEC & C-reactive protein increased & 6 & 0.3 & 0.7 \\
\hline \multirow{3}{*}{$\begin{array}{l}\text { Metabolism and } \\
\text { nutrition disorders }\end{array}$} & \multirow{2}{*}{$\begin{array}{l}\text { Appetite and general nutritional } \\
\text { disorders }\end{array}$} & \multirow{2}{*}{ Appetite disorders } & Decreased appetite & 5 & 0.3 & 0.6 \\
\hline & & & Diet refusal & 3 & 0.2 & 0.4 \\
\hline & $\begin{array}{l}\text { Electrolyte and fluid balance } \\
\text { conditions }\end{array}$ & Fluid intake decreased & Fluid intake reduced & 3 & 0.2 & 0.4 \\
\hline \multirow{12}{*}{$\begin{array}{l}\text { Musculoskeletal and } \\
\text { connective tissue } \\
\text { disorders }\end{array}$} & \multirow[b]{2}{*}{ Joint disorders } & Arthropathies NEC & Arthritis & 5 & 0.3 & 0.6 \\
\hline & & $\begin{array}{l}\text { Joint related signs and } \\
\text { symptoms }\end{array}$ & Joint swelling & 3 & 0.2 & 0.4 \\
\hline & \multirow{5}{*}{ Muscle disorders } & $\begin{array}{l}\text { Muscle infections and } \\
\text { inflammations }\end{array}$ & Myositis & 4 & 0.2 & 0.5 \\
\hline & & Muscle pains & Myalgia & 17 & 0.9 & 2.1 \\
\hline & & \multirow{2}{*}{$\begin{array}{l}\text { Muscle related signs and } \\
\text { symptoms NEC }\end{array}$} & Muscle spasms & 4 & 0.2 & 0.5 \\
\hline & & & Muscle twitching & 5 & 0.3 & 0.6 \\
\hline & & $\begin{array}{l}\text { Muscle weakness } \\
\text { conditions }\end{array}$ & Muscular weakness & 8 & 0.4 & 1.0 \\
\hline & \multirow{5}{*}{$\begin{array}{l}\text { Musculoskeletal and connective } \\
\text { tissue disorders NEC }\end{array}$} & \multirow{3}{*}{$\begin{array}{l}\text { Musculoskeletal and } \\
\text { connective tissue pain and } \\
\text { discomfort }\end{array}$} & Limb discomfort & 4 & 0.2 & 0.5 \\
\hline & & & Neck pain & 3 & 0.2 & 0.4 \\
\hline & & & Pain in extremity & 64 & 3.3 & 8.0 \\
\hline & & \multirow{2}{*}{$\begin{array}{l}\text { Musculoskeletal and } \\
\text { connective tissue signs } \\
\text { and symptoms NEC }\end{array}$} & Mobility decreased & 6 & 0.3 & 0.7 \\
\hline & & & Musculoskeletal stiffness & 9 & 0.5 & 1.1 \\
\hline
\end{tabular}

HLGT: High Level Group Terms; HLT: High Level Terms; NEC: not elsewhere classified; PT: Preferred Terms; SOC: System Organ Class.

${ }^{a}$ Denominator is all reported AEFI $(n=1,960)$.

The ten most frequently coded Preferred Terms (PT) are in bold.

\section{Denominator}

Vaccines have to undergo batch release testing before they can be marketed. Thus, the number of doses released by the national competent authority for the German market from the vaccine's launch through December 2016 was used as a surrogate for the number of doses administered.

\section{Descriptive analysis, reporting rates and}

proportional reporting ratios

For qualitative variables, absolute and relative frequencies were calculated. For quantitative variables, medians, minimums and maximums were computed. In addition, stratification by age group was performed. Reporting rates, the number of specific AEFI divided by the number of doses released, were calculated for PTs with a count of at least three.

For the 10 most frequently coded PTs, disproportionality analyses were performed by calculating proportional reporting ratios (PRR) [10] and 95\% confidence intervals $(95 \% \mathrm{Cl})$. Evans et al. [10] defined three minimum criteria for a safety signal: three or more cases, a PRR of at least two and a chi-squared of at least four. For comparison with other products used in routine immunisation with respect to these PTs, PRRs and $95 \% \mathrm{Cl}$ were calculated for meningococcal vaccines (Cpluscombinations other than type B) and pneumococcal conjugate vaccines. 
TABLE 4C

Preferred Terms (PT) for adverse events following immunisation (AEFI) with multicomponent meningococcal serogroup B vaccine (4CMenB) that were coded at least three times, grouped under High Level Terms (HLT), High Level Group Terms (HLGT) and System Organ Class (SOC), Germany, 2013-2016 (n =1,685)

\begin{tabular}{|c|c|c|c|c|c|c|}
\hline SOC & HLGT & HLT & PT & $n$ & $\begin{array}{l}\text { Relative } \\
\text { frequency } \\
(\%)^{\mathrm{a}}\end{array}$ & $\begin{array}{c}\text { Reporting } \\
\text { rate (reported } \\
\text { number of AEFI } \\
\text { per } 100,000 \\
\text { doses released) }\end{array}$ \\
\hline \multirow{21}{*}{$\begin{array}{l}\text { Nervous system } \\
\text { disorders }\end{array}$} & Headaches & Headaches NEC & Headache & 57 & 2.9 & 7.1 \\
\hline & \multirow{3}{*}{$\begin{array}{l}\text { Movement disorders (including } \\
\text { Parkinsonism) }\end{array}$} & $\begin{array}{l}\text { Dyskinesias and } \\
\text { movement disorders NEC }\end{array}$ & Movement disorder & 7 & 0.4 & 0.9 \\
\hline & & $\begin{array}{l}\text { Paralysis and paresis } \\
\text { (excluding cranial nerve) }\end{array}$ & Monoplegia & 3 & 0.2 & 0.4 \\
\hline & & $\begin{array}{l}\text { Tremor (excluding } \\
\text { congenital) }\end{array}$ & Tremor & 4 & 0.2 & 0.5 \\
\hline & \multirow{12}{*}{ Neurological disorders NEC } & $\begin{array}{l}\text { Coordination and balance } \\
\text { disturbances }\end{array}$ & Nystagmus & 3 & 0.2 & 0.4 \\
\hline & & \multirow{3}{*}{$\begin{array}{l}\text { Disturbances in } \\
\text { consciousness NEC }\end{array}$} & Loss of consciousness & 9 & 0.5 & 1.1 \\
\hline & & & Somnolence & 7 & 0.4 & 0.9 \\
\hline & & & Syncope & 8 & 0.4 & 1.0 \\
\hline & & \multirow{5}{*}{$\begin{array}{l}\text { Neurological signs and } \\
\text { symptoms NEC }\end{array}$} & Dizziness & 17 & 0.9 & 2.1 \\
\hline & & & Eye movement disorder & 4 & 0.2 & 0.5 \\
\hline & & & Meningism & 5 & 0.3 & 0.6 \\
\hline & & & Myoclonus & 4 & 0.2 & 0.5 \\
\hline & & & Unresponsive to stimuli & 3 & 0.2 & 0.4 \\
\hline & & \multirow{3}{*}{$\begin{array}{l}\text { Paraesthesias and } \\
\text { dysaesthesias }\end{array}$} & Hyperaesthesia & 9 & 0.5 & 1.1 \\
\hline & & & Hypoaesthesia & 4 & 0.2 & 0.5 \\
\hline & & & Paraesthesia & 6 & 0.3 & 0.7 \\
\hline & \multirow[b]{2}{*}{ Neuromuscular disorders } & Muscle tone abnormal & Hypotonia & 13 & 0.7 & 1.6 \\
\hline & & $\begin{array}{l}\text { Neuromuscular disorders } \\
\text { NEC }\end{array}$ & $\begin{array}{l}\text { Hypotonic-hyporesponsive } \\
\text { episode }\end{array}$ & 3 & 0.2 & 0.4 \\
\hline & \multirow{2}{*}{ Seizures (including subtypes) } & \multirow{2}{*}{$\begin{array}{l}\text { Seizures and seizure } \\
\text { disorders NEC }\end{array}$} & Febrile convulsion & 12 & 0.6 & 1.5 \\
\hline & & & Seizure & 8 & 0.4 & 1.0 \\
\hline & $\begin{array}{c}\text { Sleep disturbances (including } \\
\text { subtypes) }\end{array}$ & $\begin{array}{l}\text { Narcolepsy and } \\
\text { hypersomnia }\end{array}$ & Hypersomnia & 3 & 0.2 & 0.4 \\
\hline Product issues & $\begin{array}{c}\text { Product quality, supply, } \\
\text { distribution, manufacturing and } \\
\text { quality system issues }\end{array}$ & Product quality issues NEC & Product quality issue & 4 & 0.2 & 0.5 \\
\hline \multirow{9}{*}{ Psychiatric disorders } & Anxiety disorders and symptoms & Anxiety symptoms & Anxiety & 3 & 0.2 & 0.4 \\
\hline & Changes in physical activity & $\begin{array}{l}\text { Increased physical activity } \\
\text { levels }\end{array}$ & Restlessness & 13 & 0.7 & 1.6 \\
\hline & $\begin{array}{l}\text { Communication disorders and } \\
\text { disturbances }\end{array}$ & $\begin{array}{l}\text { Speech articulation and } \\
\text { rhythm disturbances }\end{array}$ & Screaming & 9 & 0.5 & 1.1 \\
\hline & $\begin{array}{c}\text { Depressed mood disorders and } \\
\text { disturbances }\end{array}$ & $\begin{array}{l}\text { Mood alterations with } \\
\text { depressive symptoms }\end{array}$ & Depressed mood & 3 & 0.2 & 0.4 \\
\hline & \multirow{2}{*}{$\begin{array}{l}\text { Mood disorders and disturbances } \\
\text { NEC }\end{array}$} & $\begin{array}{l}\text { Emotional and mood } \\
\text { disturbances NEC }\end{array}$ & Irritability & 6 & 0.3 & 0.7 \\
\hline & & Mood disorders NEC & Apathy & 7 & 0.4 & 0.9 \\
\hline & $\begin{array}{l}\text { Psychiatric and behavioural } \\
\text { symptoms NEC }\end{array}$ & Abnormal behaviour NEC & Abnormal behaviour & 3 & 0.2 & 0.4 \\
\hline & \multirow{2}{*}{ Sleep disorders and disturbances } & $\begin{array}{l}\text { Disturbances in initiating } \\
\text { and maintaining sleep }\end{array}$ & Insomnia & 3 & 0.2 & 0.4 \\
\hline & & Sleep disorders NEC & Sleep disorder & 6 & 0.3 & 0.7 \\
\hline \multirow{4}{*}{$\begin{array}{l}\text { Respiratory, thoracic } \\
\text { and mediastinal } \\
\text { disorders }\end{array}$} & \multirow{3}{*}{ Respiratory disorders NEC } & Breathing abnormalities & Dyspnoea & 3 & 0.2 & 0.4 \\
\hline & & $\begin{array}{l}\text { Coughing and associated } \\
\text { symptoms }\end{array}$ & Cough & 3 & 0.2 & 0.4 \\
\hline & & $\begin{array}{l}\text { Upper respiratory tract } \\
\text { signs and symptoms }\end{array}$ & Rhinorrhoea & 3 & 0.2 & 0.4 \\
\hline & $\begin{array}{l}\text { Upper respiratory tract disorders } \\
\text { (excluding infections) }\end{array}$ & $\begin{array}{c}\text { Pharyngeal disorders } \\
\text { (excluding infections and } \\
\text { neoplasms) }\end{array}$ & Pharyngeal erythema & 3 & 0.2 & 0.4 \\
\hline
\end{tabular}

HLGT: High Level Group Terms; HLT: High Level Terms; NEC: not elsewhere classified; PT: Preferred Terms; SOC: System Organ Class.

${ }^{a}$ Denominator is all reported AEFI $(n=1,960)$.

The ten most frequently coded Preferred Terms (PT) are in bold. 
Preferred Terms (PT) for adverse events following immunisation (AEFI) with multicomponent meningococcal serogroup B vaccine $(4 \mathrm{CMenB})$ that were coded at least three times, grouped under High Level Terms (HLT), High Level Group Terms (HLGT) and System Organ Class (SOC), Germany, 2013-2016 (n =1,685)

\begin{tabular}{|c|c|c|c|c|c|c|}
\hline $\mathrm{SOC}$ & HLGT & HLT & PT & $\mathrm{n}$ & $\begin{array}{l}\text { Relative } \\
\text { frequency } \\
(\%)^{\mathrm{a}}\end{array}$ & $\begin{array}{c}\text { Reporting } \\
\text { rate (reported } \\
\text { number of AEFI } \\
\text { per } 100,000 \\
\text { doses released) }\end{array}$ \\
\hline \multirow{9}{*}{$\begin{array}{l}\text { Skin and } \\
\text { subcutaneous tissue } \\
\text { disorders }\end{array}$} & Angioedema and urticaria & Urticarias & Urticaria & 24 & 1.2 & 3.0 \\
\hline & \multirow[t]{7}{*}{ Epidermal and dermal conditions } & Bullous conditions & Blister & 7 & 0.4 & 0.9 \\
\hline & & $\begin{array}{l}\text { Dermal and epidermal } \\
\text { conditions NEC }\end{array}$ & Skin discolouration & 4 & 0.2 & 0.5 \\
\hline & & Erythemas & Erythema & 100 & 5.1 & 12.5 \\
\hline & & Pruritus NEC & Pruritus & 6 & 0.3 & 0.7 \\
\hline & & \multirow{3}{*}{$\begin{array}{l}\text { Rashes, eruptions and } \\
\text { exanthems NEC }\end{array}$} & Rash & 11 & 0.6 & 1.4 \\
\hline & & & Rash generalised & 10 & 0.5 & 1.2 \\
\hline & & & Rash maculo-papular & 3 & 0.2 & 0.4 \\
\hline & Skin vascular abnormalities & $\begin{array}{l}\text { Purpura and related } \\
\text { conditions }\end{array}$ & Henoch-Schoenlein purpura & 3 & 0.2 & 0.4 \\
\hline \multirow{5}{*}{ Vascular disorders } & \multirow{3}{*}{$\begin{array}{l}\text { Decreased and non-specific blood } \\
\text { pressure disorders and shock }\end{array}$} & \multirow{2}{*}{$\begin{array}{l}\text { Circulatory collapse and } \\
\text { shock }\end{array}$} & Circulatory collapse & 3 & 0.2 & 0.4 \\
\hline & & & Peripheral circulatory failure & 3 & 0.2 & 0.4 \\
\hline & & $\begin{array}{l}\text { Vascular hypotensive } \\
\text { disorders }\end{array}$ & Hypotension & 3 & 0.2 & 0.4 \\
\hline & \multirow{2}{*}{ Vascular disorders NEC } & $\begin{array}{l}\text { Peripheral vascular } \\
\text { disorders NEC }\end{array}$ & Peripheral vascular disorder & 4 & 0.2 & 0.5 \\
\hline & & $\begin{array}{l}\text { Site-specific vascular } \\
\text { disorders NEC }\end{array}$ & Pallor & 12 & 0.6 & 1.5 \\
\hline \multicolumn{4}{|l|}{ Total for all reactions } & 1,685 & 86.0 & 210.4 \\
\hline
\end{tabular}

HLGT: High Level Group Terms; HLT: High Level Terms; NEC: not elsewhere classified; PT: Preferred Terms; SOC: System Organ Class.

${ }^{a}$ Denominator is all reported AEFI $(n=1,960)$.

The ten most frequently coded Preferred Terms (PT) are in bold.

Screening of patient records for immunemediated and neurological diseases

In order to screen for safety signals with respect to immune-mediated and neurological diseases, we used a list of 52 event outcomes published by ArnheimDahlström et al. [11] and calculated PRRs for them.

\section{Identifying adverse events of specific interest}

Furthermore, PRRs and $95 \% \mathrm{Cl}$ were also calculated for selected adverse events of specific interest: febrile convulsion/seizure, anaphylactic reaction/shock, hypotonic-hyporesponsive episode and apparent lifethreatening event.

\section{Case definitions and causality assessment}

For immune-mediated and neurological outcomes as well as for adverse events of specific interest, case definitions published by the Brighton Collaboration [12], if available, were used for case validation according to diagnostic certainty.

Causality of ICSR and AEFI was assessed according to the revised World Health Organization (WHO) classification [13]. If adequate information for causality conclusion was available, the assessment of an ICSR/ AEFI according to the algorithm described in Step 3 and Figure 3 of the WHO classification document was 'consistent causal association to immunisation' or 'inconsistent causal association to immunisation'. The association was assessed as 'indeterminate' when adequate information was available but it was impossible to assign an ICSR/AEFI to either of the aforementioned categories. If adequate information was not available, the assessment was 'unclassifiable'.

\section{Statistical analysis}

The statistical analysis was performed using the SAS version 9.4 (SAS Institute, Cary, NC, United States).

\section{Results}

Through December 2016, a total of 664 ICSR were received, 137 of which (20.6\%) were classified as serious. In most of the ICSR ( $n=626 ; 94.3 \%), 4$ CMenB was administered without concomitant vaccines. The majority of notifications $(n=600 ; 90.4 \%)$ originated from the marketing authorisation holders, while 49 (7.4\%) originated from healthcare professionals and 15 (2.3\%) from consumers.

Two-hundred-and-ninety vaccinees with reported AEFI were males ( $43.7 \%), 321$ were females $(48.3 \%)$ and sex was unknown for 53 (8.0\%). The median age was 5.0 years (range: 44 days -69 years). The majority of ICSR concerned children 2 to 11 years of age $(n=280$; 
$42.2 \%$ ) as well as infants and toddlers aged 28 days to 23 months $(n=170 ; 25.6 \%)$ (Table 1$)$.

\section{Outcomes and assessment of causality}

In 358 ICSR (53.9\%), the outcome at the time of reporting was 'recovered', in 25 ICSR (3.8\%) 'improved', in 65 ICSR (9.8\%) 'not recovered', and in 214 ICSR (32.2\%) 'unknown'. In one case (0.2\%) the vaccinee suffered permanent damage and in another case (0.2\%) the vaccinee died (Table 2). Of the ICSR, 452 (68.1\%) were assessed as 'consistent' and 50 (7.5\%) as 'inconsistent' to a causal association to immunisation. For 17 ICSR (2.6\%), causality was considered 'indeterminate' and in 145 ICSR (21.8\%), 'unclassifiable' (Table 2).

\section{Cases that resulted in sequelae or death}

There were two cases that resulted in sequelae or death. The case that resulted in sequelae was a male infant 5 months of age who received the first dose intramuscularly in the left lateral thigh. On the same day, the patient developed subcutaneous injection site abscess that was livid, persistent and fluctuating. The abscess was surgically treated, leaving behind a scar with lipolysis ca $2 \times 2.5 \mathrm{~cm}$. This case report was assessed as 'consistent' to a causal association to the administration of the vaccine. The one ICSR with a fatal outcome was a male child 28 months of age whose family history included long QT syndrome. The patient was born after induction of labour in the 39th week of pregnancy because of oligohydramnion and placental insufficiency. Medical history included a middle ear inflammation 4 months before the child's death, dry skin and cough hypersensitivity syndrome. Previous receipt of ${ }_{4} C M e n B$ administered at the age of 25 months was well tolerated. Seventeen days after intramuscular administration of the second dose, and with no concomitant medication reported, the child was affectionate and complained about throat pain in the early morning. In the late morning, the child was found lifeless lying in bed with his head on the pillow. Cardiopulmonary resuscitation was performed for 1 hour without success. Autopsy could not identify any cause of death. On the basis of the WHO algorithm for causality assessment of AEFI, this case report was classified as 'inconsistent' to a causal association to immunisation.

\section{Time to symptoms onset}

The time to symptoms onset ranged from the day of vaccination to 81 days after vaccination with the median time to symptoms onset being o days, i.e. less than 24 hours (data not shown). Regarding time to symptoms onset, differences between the age groups were negligible.

\section{Adverse events}

In Table 3, the 1,960 AEFI reported in the 664 ICSR were stratified by SOC and age group. General disorders and administrations site conditions was the SOC with the majority of AEFI $(n=977 ; 49.8 \%)$ followed by the SOCs nervous system disorders $(n=249 ; 12.7 \%)$, and skin and subcutaneous tissue disorders $(n=191$; 9.7\%). The distribution of AEFI on the SOCs was similar in all age groups. However, there was some variability regarding the HLGTs within a SOC. Within the SOC 'General disorders and administration site conditions', there was a higher percentage of body temperature conditions in infants and toddlers $(77 / 195 ; 39.5 \%)$ and children $(111 / 442 ; 25.1 \%)$ than in adolescents (10/85; $11.8 \%)$ and adults $18-59$ years of age (10/173; 5.8\%). Similarly, regarding the SOC 'Nervous system disorders', there was a higher percentage of headaches in adults 18-59 years of age (19/47) and adolescents $(12 / 24)$ than in children $(24 / 86 ; 27.9 \%)$ and infants and toddlers $(0 / 68 ; 0.0 \%)$. However, there was a higher percentage of seizures in infants and toddlers (16/68; $23.5 \%)$ and children $(10 / 86 ; 11.6 \%)$ than in adolescents (o/24) and adults $18-59$ years of age $(1 / 47)$.

Stratification by SOC and sex did not reveal any relevant differences between males and females (data not shown).

The overall reporting rate was $244.8 \mathrm{AEFI}$ per 100,000 doses released.

In Table 4, PTs that were coded at least three times are shown grouped under HLTs, HLGTs and SOCs, representing $86.0 \%$ of all AEFI $(n=1,685)$.

The 10 most frequently coded PTs, including PRRs, are presented in Table 5. Compared with meningococcal C (pluscombinations) or pneumococcal conjugate vaccines, higher PRRs were calculated for 4 CMenB particularly with respect to local reactions (injection site induration, injection site swelling and pain responses) and pyrexia. This pattern was seen in all age groups (data not shown).

Screening of patient records for safety signals for immune-mediated and neurological diseases

Notifications included six of 40 immune-mediated and three of 12 neurologic outcomes specified by ArnheimDahlström et al. [11]. For none of the outcomes, disproportionality measures were raised (data not shown).

ICSR reporting of suspected immune-mediated or neurological diseases concerned 12 individuals, seven males and five females, aged 5 months to 45 years at the time of AEFI. Three of these individuals had underlying conditions (Table 6).

\section{Serious events of specific interest}

We also looked at some rare serious events of specific interest: febrile convulsion/seizure, anaphylactic reaction/anaphylactic shock, hypotonic-hyporesponsive episode and apparent life-threatening event. The only PRR that was significantly increased was found for febrile convulsion ( $\mathrm{n}=12$; PRR 5.51 (95\% Cl: 3.069.92); chi-squared =40.74). 


\section{TABLE 5}

Comparison of the ten most frequently coded Preferred Terms (PT) following immunisation with multicomponent meningococcal serogroup B vaccine (4CMenB) with meningococcal C (plus combinations) and pneumococcal conjugate vaccines, Germany, 2013-2016

\begin{tabular}{|c|c|c|c|}
\hline Preferred Term & 4CMenB & $\begin{array}{c}\text { Meningococcal C (plus combinations) } \\
\text { vaccines }\end{array}$ & Pneumococcal conjugate vaccines \\
\hline Pyrexia & $\begin{array}{c}n=219 ; \text { PRR 2.00 (1.76-2.27); } \\
x^{2}=111.90\end{array}$ & $\begin{array}{c}n=186 ; \text { PRR } 1.36(1.18-1.56) ; \\
x^{2}=18.09\end{array}$ & $\begin{array}{c}\mathrm{n}=265 ; \text { PRR } 1.24(1.10-1.39) ; \\
x^{2}=12.21\end{array}$ \\
\hline Injection site pain & $\begin{array}{c}n=131 ; \text { PRR } 3.88(3.27-4.60) ; \\
x^{2}=268.65\end{array}$ & $\begin{array}{c}\mathrm{n}=30 ; \text { PRR } 0.68(0.48-0.98) ; \\
x^{2}=4.46\end{array}$ & $\begin{array}{c}\mathrm{n}=70 ; \text { PRR } 1.02(0.81-1.30) ; \\
x^{2}=0.04\end{array}$ \\
\hline $\begin{array}{l}\text { Injection site } \\
\text { swelling }\end{array}$ & $\begin{array}{c}\mathrm{n}=109 ; \text { PRR } 3.50(2.90-4.22) ; \\
x^{2}=187.27\end{array}$ & $\begin{array}{c}\mathrm{n}=61 ; \text { PRR } 1.54(1.20-1.98) ; \\
x^{2}=11.30\end{array}$ & $\begin{array}{c}n=124 ; \text { PRR } 2.04(1.71-2.44) ; \\
x^{2}=62.70\end{array}$ \\
\hline Erythema & $\begin{array}{c}\mathrm{n}=100 ; \text { PRR } 1.60(1.31-1.94) ; \\
\mathrm{x}^{2}=22.36\end{array}$ & $\begin{array}{c}\mathrm{n}=131 ; \text { PRR } 1.69(1.43-2.01) ; \\
\mathrm{x}^{2}=37.26\end{array}$ & $\begin{array}{c}\mathrm{n}=231 ; \text { PRR } 1.94(1.70-2.20) ; \\
\mathrm{x}^{2}=102.08\end{array}$ \\
\hline Pain in extremity & $\begin{array}{c}n=64 ; \text { PRR } 1.63(1.28-2.09) ; \\
x^{2}=15.69\end{array}$ & $\begin{array}{c}\mathrm{n}=27 ; \text { PRR } 0.55(0.37-0.80) ; \\
x^{2}=10.25\end{array}$ & $\begin{array}{c}\mathrm{n}=36 ; \text { PRR } 0.46(0.33-0.64) ; \\
x^{2}=22.67\end{array}$ \\
\hline Headache & $\begin{array}{c}\mathrm{n}=57 ; \text { PRR } 1.07(0.83-1.39) ; \\
\mathrm{x}^{2}=0.28\end{array}$ & $\begin{array}{c}\mathrm{n}=79 ; \text { PRR } 1.20(0.97-1.50) ; \\
\mathrm{x}^{2}=2.73\end{array}$ & $\begin{array}{c}\mathrm{n}=17 ; \text { PRR } 0.16(0.10-0.26) ; \\
x^{2}=76.28\end{array}$ \\
\hline $\begin{array}{l}\text { Injection site } \\
\text { induration }\end{array}$ & $\begin{array}{c}n=55 ; \text { PRR } 7.89(5.98-10.41) ; \\
x^{2}=295.09\end{array}$ & $\begin{array}{c}\mathrm{n}=12 ; \text { PRR } 1.26(0.71-2.23) ; \\
\mathrm{x}^{2}=0.63\end{array}$ & $\begin{array}{c}\mathrm{n}=28 ; \text { PRR } 1.92(1.32-2.81) ; \\
\mathrm{x}^{2}=11.75\end{array}$ \\
\hline Pain & $\begin{array}{c}n=43 ; \text { PRR } 2.39(1.77-3.24) ; \\
x^{2}=33.95\end{array}$ & $\begin{array}{c}\mathrm{n}=13 ; \text { PRR } 0.57(0.33-0.98) ; \\
\mathrm{x}^{2}=4.28\end{array}$ & $\begin{array}{c}\mathrm{n}=43 ; \text { PRR } 1.22(0.90-1.65) ; \\
\mathrm{x}^{2}=1.62\end{array}$ \\
\hline Vomiting & $\begin{array}{c}\mathrm{n}=30 ; \text { PRR } 1.07(0.75-1.53) ; \\
\mathrm{x}^{2}=0.14\end{array}$ & $\begin{array}{c}\mathrm{n}=40 ; \text { PRR } 1.16(0.85-1.58) ; \\
x^{2}=0.84\end{array}$ & $\begin{array}{c}n=55 ; \text { PRR } 1.01(0.78-1.32) ; \\
x^{2}=0.01\end{array}$ \\
\hline Fatigue & $\begin{array}{c}\mathrm{n}=29 ; \text { PRR } 1.07(0.75-1.54) ; \\
x^{2}=0.14\end{array}$ & $\begin{array}{c}\mathrm{n}=30 ; \text { PRR } 0.89(0.62-1.28) ; \\
x^{2}=0.38\end{array}$ & $\begin{array}{c}\mathrm{n}=28 ; \text { PRR } 0.53(0.36-0.76) ; \\
x^{2}=11.93\end{array}$ \\
\hline
\end{tabular}

PRR: proportional reporting ratio (95\% confidence intervals); $x^{2}$ : chi-squared.

Potential safety signals according to Evans et al. [10] in bold.

\section{Febrile convulsion/seizure}

There were 12 case reports, eight infants and toddlers less than 2 years of age and four children 3 to 5 years of age, notifying 'febrile convulsion', 10 of which were assessed as 'consistent' and two as 'inconsistent' with a causal association to immunisation.

In addition, eight ICSR, three infants and toddlers less than 2 years of age, four children between 2 and 6 years of age and one adult, were received notifying 'seizure'. Four ISCR were assessed as 'inconsistent' and one as 'consistent' with a causal association to immunisation. Causality of two ISCR was rated as 'indeterminate' and another one was assessed as 'unclassifiable'.

Three of the 20 ICSR notifying febrile convulsion/seizure met the Brighton Collaboration case definition for convulsive seizure as an AEFI [14].

Anaphylactic reaction/anaphylactic shock

There was one ICSR with the coded PT 'anaphylactic reaction' and 'anaphylactic shock' referring to a female child 11 years of age without known pre-existing allergies. This case did not fulfil the criteria of the Brighton Collaboration case definition [15]. Causality was assessed as 'unclassifiable'.

\section{Hypotonic-hyporesponsive episode}

There were three notifications of a hypotonic-hyporesponsive episode: one in a female infant 10 weeks of age, a female infant 6 months of age and a female toddler 13 months of age. All ICSR notifying hypotonichyporesponsive episode fulfilled the criteria of the Brighton Collaboration case definition [16] and all were rated as 'consistent' with a causal association to immunisation.

Apparent life-threatening event

There were two ICSR notifying an apparent life-threatening event: one in a female infant 6 months of age and one in a female infant 9 months of age. Both events resolved. In both ISCR notifying apparent life-threatening event, causality was rated as 'unclassifiable'. 


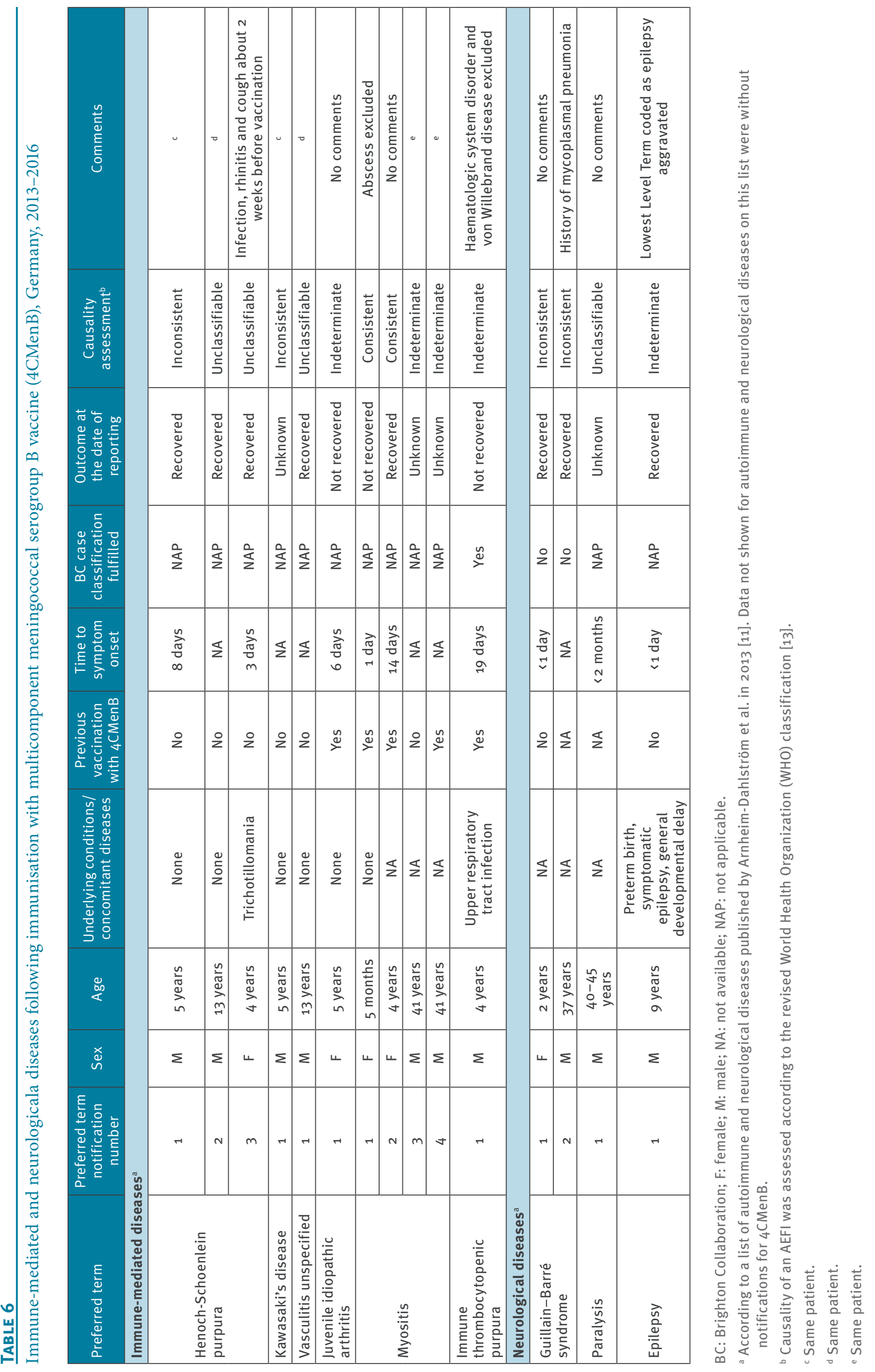




\section{Discussion}

Results from this investigation largely correspond to reactogenicity findings from phase $2 / 3$ clinical trials of 4 CMenB including a safety population of 8,776 subjects from 2 months of age who received at least one dose of ${ }_{4} C M e n B$ [17-23]. In general, the AEFI reports are consistent with the known safety profile of ${ }_{4} \mathrm{CMenB}$ as reflected in the Summary of Product Characteristics which is dominated by administration site reactions. Analyses stratified by SOC and age group as well as SOC and sex did not reveal any age- or sex-related safety signals. Nevertheless, our analyses revealed some age-related differences within SOCs, e.g. a higher percentage of body temperature conditions/seizures in infants and toddlers compared with older individuals, which can easily be explained by age-specific background incidence rates. Regarding headaches, which were more frequently reported in adolescents and adults compared with younger individuals, this may be ascribed to the fact that infants and smaller children may be unable to report and/or correctly localise pain.

Screening of patient records for immune-mediated and neurological diseases according to an outcome list published by Arnheim-Dahlström et al. [11] did not generate any safety signal in terms of increased PRR. Continuous monitoring is considered sufficient for unexpected AEFI not listed in the Summary of Product Characteristics such as Henoch-Schoenlein purpura and myositis. In a published case of myositis after receipt of ${ }_{4} C M e n B$ [24], magnetic resonance imaging suggested an incorrect placement of the vaccine into the shoulder joint or the shoulder bursa. This may have contributed to the development of a condition called 'shoulder injury related to vaccine administration' [25]. Injecting vaccine into the synovial tissue of the joint or bursa may cause severe inflammation. Notably, this case reveals off-label use as according to the Summary of Product Characteristics, in infants, the vaccine should be administered into the vastus lateralis muscle. In the other paediatric case report, myositis may have developed as a result of a hygiene problem since a smear test was positive for Staphylococcus aureus. The adult patient case report also involved off-label use and lacked information on how diagnosis of myositis was confirmed.

There were a total of 20 ISCR notifying seizures with and without fever (listed in the Summary of Product Characteristics as uncommon, i.e. $\geq 1 / 1,000$ to $<1 / 100$ adverse reaction). Only three of the 20 case reports met the Brighton Collaboration case definition for convulsive seizure as an AEFI [14]. This may be because the Brighton Collaboration case definition requires ' $a$ witnessed loss of consciousness' or a 'history of unconsciousness' and that in most of the ISCR, 'unconsciousness' was not included in the description of signs and symptoms. Of note, a significantly increased PRR was found for 'febrile convulsion' but not for 'seizure' without documented fever. This is in line with the significantly increased PRR for pyrexia which is listed in the
Summary of Product Characteristics as a very common $(\geq 1 / 10)$ adverse reaction.

In point 4.5 of the Summary of Product Characteristics of ${ }_{4} \mathrm{CMenB}$, prophylactic use of paracetamol is recommended to reduce the incidence and severity of fever because studies have revealed that paracetamol has this effect without affecting the immunogenicity of either ${ }_{4}$ CMenB or routine vaccines. While Public Health England recommended the prophylactic use of paracetamol for this vaccine [26], the German National Immunization Technical Advisory Group neither recommended nor discouraged such. A recent publication even reported an increase in accident and emergency presentations for $\mathrm{AEFI}$ after introduction of the $4 \mathrm{CMenB}$ in United Kingdom from September 2013 to August 2016 despite prophylactic use of paracetamol [27]. As the meningococcal $B$ vaccination has not yet been introduced in the vaccination schedule and thus, the vaccination coverage is supposed to be low, there is currently no possibility to determine whether the situation is similar in Germany. The high reactogenicity of 4CMenB compared with other vaccines used for routine vaccination was also confirmed in a recent review on clinical experience with vaccines against group $B$ meningococcal disease [28].

There were three notifications of hypotonic-hyporesponsive episode (listed in the Summary of Product Characteristics) and two of apparent life-threatening event (not listed in the Summary of Product Characteristics) for which the diagnosis of apparent life-threatening event was considered uncertain as both ICSR notifying apparent life-threatening event fulfilled the criteria of the Brighton Collaboration case definition for hypotonic-hyporesponsive episode [16]. Hypotonic-hyporesponsive episode is labelled for several childhood vaccines.

There was one notification of sudden unexpected death (SUD) referring to a male child 28 months of age with a family history of inherited arrhythmogenic disease (a distant relative with a heterozygous genotype). Molecular genetic analyses to confirm or exclude a congenital long QT syndrome in the patient were performed, but results were not provided to us. In-depth cardiological diagnostics of the child's parents were without indication of channelopathies. A recent publication revealed that channelopathies are important causes of SUD in infancy [29]. Sanchez et al. [30] who investigated 789 consecutive cases of SUD in individuals below 50 years of age and included genetic analysis in the investigation, found cardiac disease to be the most important cause of SUD. Oshima et al. even suggested performing genetic screening in addition to biochemical and physiological screening during the neonatal period to identify individuals at risk of arrhythmia or metabolic disease; affected infants could thus be diagnosed and treated earlier, and many cases of SUD could be prevented [31]. When assessing the causality of $\mathrm{AEFI}$, background incidence rates have 
to be considered. Winkel et al. [32] determined the incidence rate of SUD in individuals 1 to 18 years of age in Denmark to be 1.5 cases per 100,000 person-years, and the highest possible incidence rate of sudden cardiac death as 1.1 cases per 100,000 person-years. Risgaard et al. 2014 [33] determined the age-specific sudden cardiac death incidence rate of children 2 to 3 years of age in Denmark to be 0.5 cases per 100,000 personyears. Based on data for the year 2015 obtained from The Federal Statistical Office of Germany upon request, the causes of death coded as ICD-10 R96 (Other sudden death, cause unknown), R98 (Unattended death), R99 (Other ill-defined and unspecified causes of mortality), and 146 (Sudden cardiac death, so described) were reported for four, nine, 23 and three children aged 1 to 5 years, respectively. Considering that $2,868,825$ children 1 to 5 years of age lived in Germany in 2015, this corresponds to an incidence rate for R96, R98, R99, and I46 of $0.1,0.3,0.8$ and 0.1 cases per 100,000 person-years, respectively. In the light of the above, it is expected that coincident SUD case reports unrelated to vaccination will be notified.

\section{Strengths}

A major strength of this work is that because of the reporting obligation of healthcare professionals and marketing authorisation holders, the database used in this analysis is the most comprehensive AEFI collection in Germany. In order to receive more detailed information, follow-up reports were requested in almost all serious ICSR on a routine basis. Case definitions established by the Brighton Collaboration, if available, were used to validate the diagnoses notified by the healthcare professionals regarding immune-mediated and neurological diseases, as well as adverse events of specific interest. This allowed for objectifying the information provided and enabling comparisons with previous and future investigations on the safety profile of 4 CMenB. In addition, we strictly adhered to the WHO criteria for causality assessment of AEFI which use Brighton Collaboration case definitions if applicable, overall scientific evidence and information concerning the individual case report.

\section{Limitations}

Despite the legal obligation to notify AEFI, there is, of course, under-reporting and it is unclear to what extent. Meningococcal B vaccination has not yet been included in the national immunisation schedule and consequently, vaccine coverage data based on anonymised health insurance claims data were not available. The number of doses released was used as a surrogate for the number of doses administered. It has to be assumed that not all doses released were administered. Thus, the reporting rates presented within the scope of this work may be underestimated. Hence, for signal detection purposes we also used a disproportionality measure which is not based on exposure.

\section{Conclusions}

Vaccination against bacterial meningitis caused by Neisseria meningitidis serogroup B, in general, is well tolerated. We analysed data from post-marketing surveillance over a period of 3 years by strictly adhering to WHO criteria for causality assessment and combining these findings with results of reporting rates and disproportionality analyses. Post-marketing surveillance of vaccines in Germany did not indicate any emerging safety signal. Rather, results were consistent with the known safety profile of the 4 CMenB.

\section{Acknowledgements}

We would like to thank all healthcare professionals, marketing authorisation holders and vaccinees who notified adverse events following immunisation.

\section{Conflict of interest}

None declared.

\section{Authors' contributions}

DM initiated the project, was involved in the data management, commented on the draft, read and approved the final manuscript.

DO performed the statistical analyses, drafted and finalised the manuscript.

BK supervised the project, was involved in the medical assessment of case reports, commented on the draft, read and approved the final manuscript.

\section{References}

1. European Centre for Disease Prevention and Control (ECDC). Annual epidemiological report for 2015. Invasive meningococcal disease. Stockholm: ECDC; 2017. Available from: https://ecdc.europa.eu/sites/portal/files/documents/ AER_for_2015-meningococcal-disease.pdf

2. Granoff DM. Review of meningococcal group B vaccines. Clin Infect Dis. 2010;50(s2) Suppl 2;S54-65. https://doi. org/10.1086/648966 PMID: 20144017

3. Harrison LH. Vaccines for prevention of group B meningococcal disease: Not your father's vaccines. Vaccine. 2015;33(Suppl 4):D32-8. https://doi.org/10.1016/j.vaccine.2015.05.101 PMID: 26116255

4. Gorringe AR, Pajón R. Bexsero: a multicomponent vaccine for prevention of meningococcal disease. Hum Vaccin Immunother. 2012;8(2):174-83. https://doi.org/10.4161/hv.18500 PMID: 22426368

5. Infektionsschutzgesetz (IfSG). [Protection against Infection Act]. 1 Jan 2001. German. Available from: http://www.gesetzeim-internet.de/ifsg/index.html

6. Medicinal Products Act (Arzneimittelgesetz - AMG). 24 Aug 1976. Available from: https://www.gesetze-im-internet.de/ englisch_amg/index.html

7. European Medicines Agency (EMA). ICH Topic E 2 A Clinical Safety Data Management: Definitions and Standards for Expedited Reporting. CPMP/ICH/377/95. London: EMA; 1995. Available from: www.ema.europa.eu/docs/en_GB/document library/Scientific guideline/2009/09/WC500002749.pdf

8. Introductory Guide. MedDRA Version 20.1. McLean, Virginia: Medical Dictionary for Regulatory Activities (MedDRA) Maintenance and Support Services Organization (MSSO); Sep 2017. [Accessed 19 Apr 2018]. Available from: https://www. meddra.org/sites/default/files/guidance/file/intguide_20_1_ english_o.pdf 
9. International Council for Harmonisation of Technical Requirements for Pharmaceuticals for Human Use (ICH) Expert Working Group. Clinical investigation of medicinal products in the pediatric population E11. Geneva: ICH; 20 Jul 2000. Available from: https://www.ich.org/fileadmin/Public Web_Site/ICH_Products/Guidelines/Efficacy/E11/Step4/ E11 Guideline.pdf

10. Evans SJ, Waller PC, Davis S. Use of proportional reporting ratios (PRRs) for signal generation from spontaneous adverse drug reaction reports. Pharmacoepidemiol Drug Saf. 2001;10(6):483-6. https://doi.org/10.1002/pds.677 PMID: 11828828

11. Arnheim-Dahlström L, Pasternak B, Svanström H, Sparén $P$, Hviid A. Autoimmune, neurological, and venous thromboembolic adverse events after immunisation of adolescent girls with quadrivalent human papillomavirus vaccine in Denmark and Sweden: cohort study. BMJ. 2013;347(octo9 4):f5906. https://doi.org/10.1136/bmj.f5906 PMID: 24108159

12. World Health Organization (WHO). Module 5: Vaccine safety institutions and mechanisms. Brighton Collaboration - setting standards in vaccine safety. Geneva: WHO. [Accessed $23 \mathrm{Apr}$ 2018]. Available from: http://vaccine-safety-training.org/ brighton-collaboration.html

13. Causality assessment of an adverse event following immunization $(\mathrm{AEFI})$. User manual for the revised WHO classification. Geneva: World Health Organization; 2013. Available from: http://www.who.int/vaccine_safety/ publications/aevi_manual.pdf

14. Bonhoeffer J, Menkes J, Gold MS, de Souza-Brito G, Fisher MC, Halsey N, et al. Generalized convulsive seizure as an adverse event following immunization: case definition and guidelines for data collection, analysis, and presentation. Vaccine. 2004;22(5-6):557-62. https://doi.org/10.1016/j. vaccine.2003.09.008 PMID: 14741144

15. Rüggeberg JU, Gold MS, Bayas J-M, Blum MD, Bonhoeffer J, Friedlander S, et al. Anaphylaxis: case definition and guidelines for data collection, analysis, and presentation of immunization safety data. Vaccine. 2007;25(31):5675-84. https://doi.org/10.1016/j.vaccine.2007.02.064 PMID: 17448577

16. Buettcher M, Heininger U, Braun M, Bonhoeffer J, Halperin S, Heijbel $\mathrm{H}$, et al. Hypotonic-hyporesponsive episode (HHE) as an adverse event following immunization in early childhood: case definition and guidelines for data collection, analysis, and presentation. Vaccine. 2007;25(31):5875-81. https://doi. org/10.1016/j.vaccine.2007.04.061 PMID: 17537554

17. Findlow J, Borrow R, Snape MD, Dawson T, Holland A, John TM, et al. Multicenter, open-label, randomized phase II controlled trial of an investigational recombinant Meningococcal serogroup B vaccine with and without outer membrane vesicles, administered in infancy. Clin Infect Dis. 2010;51(10):1127-37. https://doi.org/10.1086/656741 PMID: 20954968

18. Snape MD, Dawson T, Oster P, Evans A, John TM, Ohene-Kena $B$, et al. Immunogenicity of two investigational serogroup $B$ meningococcal vaccines in the first year of life: a randomized comparative trial. Pediatr Infect Dis J. 2010;29(11):e71-9. PMID: 20844462

19. Gossger N, Snape MD, Yu L-M, Finn A, Bona G, Esposito $\mathrm{S}$, et al. Immunogenicity and tolerability of recombinant serogroup B meningococcal vaccine administered with or without routine infant vaccinations according to different immunization schedules: a randomized controlled trial. JAMA. 2012;307(6):573-82. https://doi.org/10.1001/jama.2012.85 PMID: 22318278

20. Vesikari T, Esposito S, Prymula R, Ypma E, Kohl I, Toneatto $D$, et al. Immunogenicity and safety of an investigational multicomponent, recombinant, meningococcal serogroup $B$ vaccine (4CMenB) administered concomitantly with routine infant and child vaccinations: results of two randomised trials. Lancet. 2013;381(9869):825-35. https://doi.org/10.1016/ S0140-6736(12)61961-8 PMID: 23324563

21. Esposito S, Prymula R, Zuccotti GV, Xie F, Barone M, Dull PM, et al. A phase 2 randomized controlled trial of a multicomponent meningococcal serogroup B vaccine, 4 CMenB, in infants (II). Hum Vaccin Immunother. 2014;10(7):2005-14. https://doi. org/10.4161/hv.29218 PMID: 25424810

22. Findlow J, Bai X, Findlow $H$, Newton E, Kaczmarski E, Miller E, et al. Safety and immunogenicity of a fourcomponent meningococcal group $B$ vaccine $(4 C M e n B)$ and a quadrivalent meningococcal group ACWY conjugate vaccine administered concomitantly in healthy laboratory workers. Vaccine. 2015;33(29):3322-30. https://doi.org/10.1016/j. vaccine.2015.05.027 PMID: 26025807

23. Lee HJ, Choe YJ, Hong Y-J, Kim K-H, Park SE, Kim Y-K, et al. Immunogenicity and safety of a multicomponent meningococcal serogroup $B$ vaccine in healthy adolescents in Korea--A randomised trial. Vaccine. 2016;34(9):11806. https://doi.org/10.1016/j.vaccine.2016.01.033 PMID: 26826544

24. Tenenbaum T, Niessen J, Schroten H. Severe Upper Extremity Dysfunction After 4CMenB Vaccination in a Young Infant. Pediatr Infect Dis J. 2016;35(1):94-6. PMID: 26379162

25. Atanasoff S, Ryan T, Lightfoot R, Johann-Liang R. Shoulder injury related to vaccine administration (SIRVA). Vaccine. 2010;28(51):8049-52. https://doi.org/10.1016/j. vaccine.2010.10.005 PMID: 20955829

26. Public Health England. Using paracetamol to prevent and treat fever after MenB vaccination. London: National Health Service; 2015. Available from: https://assets.publishing.service.gov. uk/government/uploads/system/uploads/attachment data/ file/483408/9413-paracetamol-menB-2page-A4-08-web.pdf

27. Nainani V, Galal U, Buttery J, Snape MD. An increase in accident and emergency presentations for adverse events following immunisation after introduction of the group B meningococcal vaccine: an observational study. Arch Dis Child. 2017;102(10):958-62. https://doi.org/10.1136/ archdischild-2017-312941 PMID: 28794096

28. Wilkins AL, Snape MD. Emerging clinical experience with vaccines against group B meningococcal disease. Vaccine. 2017. https://doi.org/10.1016/j.vaccine.2017.07.056 PMID: 28778616

29. Hertz CL, Christiansen SL, Larsen MK, Dahl M, FerreroMiliani L, Weeke PE, et al. Genetic investigations of sudden unexpected deaths in infancy using next-generation sequencing of 100 genes associated with cardiac diseases. Eur J Hum Genet. 2016;24(6):817-22. https://doi.org/10.1038/ ejhg.2015.198 PMID: 26350513

30. Sanchez O, Campuzano O, Fernández-Falgueras A, SarquellaBrugada G, Cesar S, Mademont I, et al. Natural and Undetermined Sudden Death: Value of Post-Mortem Genetic Investigation. PLoS One. 2016;11(12):e0167358. https://doi. org/10.1371/journal.pone.0167358 PMID: 27930701

31. Oshima Y, Yamamoto T, Ishikawa T, Mishima H, Matsusue A, Umehara T, et al. Postmortem genetic analysis of sudden unexpected death in infancy: neonatal genetic screening may enable the prevention of sudden infant death. J Hum Genet. 2017;62(11):989-95. https://doi.org/10.1038/jhg.2017.79 PMID: 28747690

32. Winkel BG, Risgaard B, Sadjadieh G, Bundgaard H, Hauns $\emptyset$ $\mathrm{S}$, Tfelt-Hansen J. Sudden cardiac death in children (1-18 years): symptoms and causes of death in a nationwide setting. Eur Heart J. 2014;35(13):868-75. https://doi.org/10.1093/ eurheartj/eht509 PMID: 24344190

33. Risgaard B, Winkel BG, Jabbari R, Behr ER, Ingemann-Hansen 0 , Thomsen JL, et al. Burden of sudden cardiac death in persons aged 1 to 49 years: nationwide study in Denmark. Circ Arrhythm Electrophysiol. 2014;7(2):205-11. https://doi. org/10.1161/CIRCEP.113.001421 PMID: 24604905

\section{License and copyright}

This is an open-access article distributed under the terms of the Creative Commons Attribution (CC BY 4.0) Licence. You may share and adapt the material, but must give appropriate credit to the source, provide a link to the licence, and indicate if changes were made.

This article is copyright of the authors, 2018. 